\title{
Healthcare organizations and decision-making: leadership style for growth and development
}

1 Alenka Žibert

2 Andrej Starc

1 University Medical Centre Ljubljana, Ljubljana, Slovenia

2 Faculty of Health Sciences, Chair of Public Health, University of Ljubljana Ljubljana, Slovenia

\section{Abstract

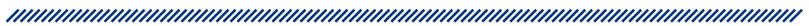

Background: Change management has become a key instrument in every organization and is crucial for their survival since changes have become unavoidable. The manner in which changes are introduced in everyday practice is an important component of change management. Managing change involves thoughtful planning and implementation, as well as the involvement of employees. Success is based on an appropriate managerial approach since management styles have a direct impact on the introduction of change by transforming employee attitudes. The aim of the study was to examine the impact of different leadership styles onthe success of introducing changes.

Methods: We used a quantitative methodology. The instrument used was a validated questionnaire with closed questions. Four Slovenian healthcare centers were included in the study.

Results: The success of the introduced changes statistically positively correlates with the transformational leadership ( $p<0.05)$, and negatively correlates with the
Laissez-faire leadership $(p<0.05)$. The assessed effectiveness of leadership styles positively correlates with the transformational, transactional, and Laissez-faire leadership $(p<0.05)$. However, within the assessed effectiveness of leadership styles, and the satisfaction with the introduced changes the strong link was observed in transformational leadership.

Conclusions: Over the past decades, the emphasis on change has proven to be a key feature of organizational success. Changes are introduced and based on a proper management style, which has a direct impact on the working environment.

Keywords: change management, organizational change, healthcare, health organizations, leadership styles, transformational leadership, transactional leadership, employee satisfaction.

Article received: 25.12.2017.

Article accepted: 15.04.2018.

DOI: $10.24141 / 1 / 4 / 2 / 7$

Corresponding author:

Asst. Prof. Andrej Starc, PhD, BSc(RN), BSc(Ed.)

Faculty of Health Sciences, Chair of Public Health, Slovenia, University of Ljubljana

Zdravstvena pot 5, 1000 Ljubljana, Slovenia

$\mathrm{T}:+38613001111$

F: +35613001119

Email: andrej.starc@guest.arnes.si 


\section{Introduction}

Historically, leadership as a key concept of management has been viewed as an extensive, interesting and influential factor. Inseparably linked with complexity and many polemics, a detailed understanding of leadership as a phenomenon has been a subject dealt with by many researchers. Leadership, in general, is a component or a function of the management and states "directing the people by influencing their behaviour as well as an interaction between groups to achieve the organizational goals"1. Leadership should be understood as the basic concept in organizational functioning.

Leadership is seen as a notable yet at the same time the least understandable concept $\mathrm{t}^{2,3}$. In addition, depending on the point of view, several definitions of leadership can be found. The similarities between them should be seen as a set of attributes, behaviours, attitudes, perceptions or as various types of impacts on employees, goals and organizational culture ${ }^{4}$. The most obvious controversy is to define leadership as an organizational process or as individual behaviour, thereby establishing a boundary between managers and leaders. Managers 'do the right thing', deal with the issue of 'how', carry out their work based on their responsibility and authority, and take care of their employees 5 . Based on the complexity, leadership also represents an elusive and complex phenomenon. Authors have found many terms, but leadership still remains insufficiently defined ${ }^{6,7}$. There are two main areas of interest; the first is studies carried out by experts of various sciences and disciplines, while the second is the complexity of the leadership phenomenon itself $f^{1,9}$.

Chronologically, leadership change is perceived as a phenomenon typical of organizations and a force of change, defined as an ability that affects tracking ${ }^{3}$. However, there is also a simpler definition that leadership should be understood as a process with which one person influences another person to achieve a specific goal ${ }^{7,8,10-14}$. Similarly, Možina et al..$^{15}$ argue that leadership represents the ability to influence, encourage and direct employees to the desired goals ${ }^{16}$.

Leadership should be seen not just as a unique act, but as a set of events, oriented on routing and monitoring. A successful leader cooperates with others to create a favourable atmosphere for achieving organizational goals $^{17}$. But, a successful leader does not also mean a successful manager ${ }^{15}$. It can be argued that leadership is a process of influencing an employee(s) to act. Robbins and Coulter ${ }^{27}$ define a leader as a person who influences other persons with authority. Hitt et al. ${ }^{11}$ declare that leadership is an interpersonal process and incorporates the influence of another person(s).

There is an ongoing need to reinforce the leadership concept in the healthcare system. Several strategic documents point out the necessity of training healthcare professionals as team leaders, based on knowledge of leadership and management in healthcare. Nowadays, many healthcare professionals face this challenge, and are often expected to carry out double work: the professional and the leadership part ${ }^{17}$.

As far as the leadership part of work is concerned, many healthcare professionals are not trained (enough), which is reflected in inappropriate leadership and/ or inadequate managerial capacity ${ }^{18,19}$. Studies in the field of healthcare argue that clinical expertise remains most important and the idea of being a 'good manager' is mostly based on clinical expertise ${ }^{17,20}$. In addition to clinical expertise, a competency profile in the healthcare system should include personal characteristics, interpersonal skills, the ability to think critically, plan, communicate, initiate change, motivate, knowledge of the healthcare system, and the possession of good management and business skills ${ }^{17}$. This is because two common denominators dominate the concept of leadership: obtaining knowledge through others based on an interactive relationship, and with the influence of mutual goals ${ }^{21}$.

\subsection{Management of changes}

In order to achieve growth and/or development, changes and adaptation are absolutely necessary. In (healthcare) organizations, everyday processes are faced with changes, which are defined as processes of transitioning from one condition to another ${ }^{22}$. Within changes, technology, social habits, values and people are also involved ${ }^{23}$. Changes are not something new, but are an essential part of personal and professional life ${ }^{24,25}$. Changes are natural and inevitable effects, and organizations should grow and develop based on constant and quickly applied changes and adaptation ${ }^{26}$.

Several changes are manifested in organizations ${ }^{28}$ :

- technical and technological: introduction of new technologies or technological processes;

- physical: changes of location; 
- organizational: restructuring the organizational structure, processes, and culture, and

- personal: changing individuals or changing the way employees work.

When implementing changes in a healthcare organization, various problems and risks often arise, especially in the form of resistance and lack of commitment. The reason for this may lie in the lack of effective leadership $^{29,30}$. Inevitably, the introduction of small or big changes directly influences people, and consequently also influences their productivity ${ }^{6,24,26,30-41}$.

Since adequate leadership is a prerequisite in the management of organizational changes ${ }^{6,37,42-45}$, inadequate leadership could contribute to (in)voluntary reversal of the process of changing ${ }^{46-47}$, while an appropriate way of managing changes may reduce the employee's uncertainty and, in the form of teamwork, increase their productivity ${ }^{48-50}$.

According to empirical findings, the milestone for an effective insertion of changes is the application of a transformational, transactional and charismatic leadership style ${ }^{42,51-53}$. Leaders should behave in accordance with the changes being attempted, and should be equipped with specific skills, behaviours and abilities, be self-motivated and have problem-solving skills, the ability to negotiate and emergency, as well as to communicate, provide accurate information and strive for less centralization ${ }^{54-55}$.

\subsection{Resistance to changes}

Changes largely encounter resistance ${ }^{56}$. But there can be no change as long as the pressure does not exceed the resistance or until the resistance is reduced by as much as the pressure triggers the change ${ }^{15}$. Change without resistance does not represent a change, but is merely an illusion of change - it is only a continuation of the situation as it currently corresponds to the majority ${ }^{57}$. Resistance to change relates primarily to the behavior of employees who prevent the implementation of the change ${ }^{48,58}$. As a rule, professionals and other staff are inclined to resist changes that are presumed to jeopardize their fundamental interests, values, and practices, and to negatively affect individuals and reduce their autonomy. Subsequently, moving people from their 'comfort zone' means moving them from a familiar and safe to an uncertain environment. The process of change leads to unpredictable processes and events that bring back different opportunities, but also problems $s^{59,61-66}$. Professionals in healthcare organi- zations often show resistance to changes, based on a lack of knowledge and experience, a lack of belief that changes are necessary as well as a questioning of the importance of change for an individual. All this may lead to a loss of motivation for change, as well as increased stress levels, feelings of denial, a lack of understanding and uncertainty ${ }^{28,67}$.

\subsection{Management of changes in healthcare organizations}

Healthcare organizations around the world face numerous challenges ${ }^{24,68-69}$. Researchers Fedor et al. ${ }^{70}$ report on important challenges in healthcare organizations: financial challenges (lowering costs), the need to introduce health reforms and care for uninsured citizens. But many results show that change in the clinical practice is a highly complex phenomenon every time ${ }^{23,71}$.

The prevailing discourse relating to change in medical literature is that changes are extremely desirable processes and are synonymous with progress. Therefore, the need for change is shown to be reasonable and almost unavoidable ${ }^{72}$. Health organizations are increasingly compelled towards the adaptation and development of new medical information, technologies and relationships with other (health) systems ${ }^{73}$, the development of healthcare professionals and also aging populations ${ }^{74}$. As a consequence, healthcare institutions are constantly changing ${ }^{75-76}$, although healthcare organizations are considered to be extremely rigid systems that are relatively difficult to adapt to changes ${ }^{74}$. Therefore, the process should be principally directed at leadership, organizational culture and in the team, the approach to producing changes ${ }^{77}$. Many healthcare organizations are forced to maintain or improve their performance and quality of care as raising the quality of healthcare is one of the priorities of healthcare systems around the world ${ }^{78}$. Healthcare organizations did not respond as rapidly as the other industries ${ }^{79}$. The problem with a successful implementation of the program to introduce a change can be explained by the gap between the strategy to introduce the change and its implementation ${ }^{80-81}$. Despite notable changes in demography and the emergence of new diseases, the supply of healthcare organizations has not changed significantly in the last thirty years ${ }^{82}$, and the ability to implement change has become the key factor in differentiating between successful and unsuccessful healthcare organizations as well as the indicator of successful management in the 21 st century ${ }^{83}$. 
References to the management of changes highlight the leader's behaviour whose aim is to "implement" chang$e^{77,84-85}$ since such behaviour is linked to success ${ }^{54}$. Leaders must become key promoters by introducing individuals to the processes of decision-making since changes do not occur unless individuals and groups change ${ }^{86}$, and become possible only through the use of appropriate managerial approaches ${ }^{87-88}$.

The current literature states that transformation management is necessary for the change to succeed ${ }^{89}$. Transformation leaders show a high level of trust and self-esteem, which inspires employees to have a common vision of why and how to successfully introduce changes ${ }^{90}$. In addition, this style of leadership promotes commitment and provides the necessary autonomy. Researchers Van Rossum et al. ${ }^{87}$ report that transformation and labour flexibility are the main success factors that facilitate the introduction of new changes.

\subsection{The connection between leadership styles and implementation of changes}

Studying the context and the content of changes shows many reasons for their proper management. In many documents, management is referred to as the facilitator or a factor in the successful implementation of changes ${ }^{73,89,91-94}$. Thefirstmanagementtheorieswereconcerned with determining the personality traits of the leader ${ }^{15}$, and subsequently, the attention of researchers eventually moved to the study of their concrete behavior ${ }^{95}$.

\subsection{Transformational leadership style}

Bass $^{96}$ contributed greatly to the development of the transformational style of management, and published a comprehensive concept of transformational guidance in 1985. Transformational leaders are visionary individuals who have a high level of trust in the organization, clearly articulate basic values, have great cognitive skills, believe in people, and are sensitive to the needs of their employees. They operate on the basis of charisma, cooperation, and inspiration ${ }^{15}$, and transformational management is often observed as the most effective management behavior ${ }^{9,97-101}$.

Many researchers regularly emphasize the importance of transformational leadership during the processes of introducing changes ${ }^{53,103}$, since, in the context of change, respect for employees and their individuality is extremely important. During the times of change, leaders need to set up a strong base of individualized support to employees who rely on the support of their leader in difficult situations ${ }^{87}$.

Other studies describe the direct relationship between transformational management and the commitment of employees to changes ${ }^{42,104}$. Positive relationships between transformational guidance and a higher motivation of employees compared with other management styles were found ${ }^{105,106}$. Transformational leaders are actively embracing the approach to the implementation of changes ${ }^{39,54}$. The leader's behaviour influences the characteristics of the change process, which consequently influences the commitment of employees to change ${ }^{98}$. From the transformational management, the expectation of the leaders is aimed at identifying the needs for changes, co-creating approaches to changes, and promoting both planned and emerging changes ${ }^{98,107}$.

\subsection{Transactional leadership style}

Transactional leadership style is a leading system based on reward and exemption management ${ }^{108}$ and consists of simple and comprehensive exchanges between the manager and employees, who exchange awards, recognition and other services to promote the desired effect $\mathrm{t}^{1,15,97,101,109}$. Leaders use awards as a source of power to reach an agreement ${ }^{100}$. The transaction manager works to achieve clarity and preserve the status quo, and operates quite similarly to the classical management method ${ }^{79,110}$. The performed studies show that the combination of transactional and transformational style management provides the most effective management results ${ }^{111}$.

\subsection{Laissez-faire leadership style}

Laissez-faire management is often also understood as 'non-governance' in the existing literature ${ }^{4,111}$. This passive management style is often considered ineffective as these leaders have little or no impact on their workgroup ${ }^{100}$. Such leaders avoid acceptance of responsibility, are absent and do not follow the requests for help and resist the expression of opinions on important issues $^{112}$. This allows their subordinates to have a high degree of independence and freedom of action ${ }^{101}$. The main characteristics of this management style are the poor quality of work, inefficiency in the organization and a high level of employee dissatisfaction ${ }^{4}$. The management of a Laissez-faire system is often associated with negative organizational results ${ }^{113}$. 


\section{Methodology}

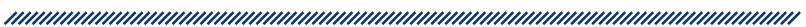

We used a quantitative methodology. Based on the authors approval we used a validated questionnaire which was adapted for our research114,115. The sample consisted of 112 healthcare providers. All of the healthcare providers were recruited from the Healthcare center (HCC) Adolf Drolc Maribor, Kranj, Ljubljana, and Izola. Ethical approval was obtained prior to the commencement of healthcare centers. For the quantitative analysis, a validated questionnaire was used. In the initial phase, a pilot study was conducted in Healthcare center Trbovlje, which lasted from 2 to 9 February 2018. Along with the participants' demographics, the questionnaire included statements (5-scale Likert), which measured the individuals' statement for the type of introduced change $(\alpha=0.86)$, leadership styles: transformational style $(\alpha=0.95)$, transactional style $(\alpha=0.86)$, Laissezfaire $(\alpha=0.77)$, and the effectiveness of used management style $(\alpha=0.97)$. The questionnaire contained 40 closed-ended questions. Based on the pilot study we removed 8 claims from 2 nd question, and 1 claim from the 4th question. Following validation, the research lasted from 13 March to 13 May 2018. In each healthcare center, we distributed 50 questionnaires. We received 19 questionnaires from HCC Izola, 38 HCC Maribor, 15 HCC Kranj, and 42 HCC Ljubljana. The final sample was composed of 112 individuals, and the realization of the sample was 56\%. Data were inserted and analyzed using SPSS (Statistical Package for Social Sciences) 24. For the statistical analysis, we used the factor analysis.

We tested the following hypotheses:

$\mathrm{H}$ 1: transformational leadership is positively related to the perceived performance of the introduced changes.

$\mathrm{H} 2$ : transactional management is also positively related to the effectiveness of introduced changes, but to a lesser degree than the transformation.

H3: laissez-faire leadership is negatively linked to the perceived performance of the introduced changes

H4: transformational leadership is positively linked to effectiveness

H5: transformational leadership is positively related to higher employees satisfaction

\section{Results}

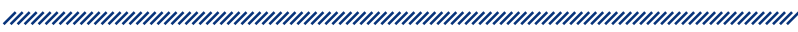

The sample consisted of 10 (8.9\%) males and 101 (90.2 $\%)$ females. One participant did not declare their gender (Table 1). The age groups consisted of $29,5 \%$ of the participants from 41 to 50 years, $25.8 \%$ from 51 to 60 years, and $26.8 \%$ from 31 to 40 years, $12.5 \%$ of the participants younger than 30 years. One participant was older than 60 years and one did not declaire their age (Table 2a-b). Eighty-eight (78.6\%) declared that in their organization incremental changes and $24(21.4 \%)$ radical changes occurred.

\begin{tabular}{|c|c|c|c|}
\hline \multicolumn{4}{|c|}{ Table 1: Structure of respondents by gender } \\
\hline & Gender & $\mathrm{f}$ & $\%$ \\
\hline & Male & 10 & 8.9 \\
\hline & Female & 101 & 90.2 \\
\hline & Total & 111 & 100 \\
\hline Missing & & 1 & \\
\hline Total & & 112 & 100 \\
\hline Legend: $\mathrm{f}$ - frequency, \% - percent & & \\
\hline
\end{tabular}

\begin{tabular}{|c|c|c|c|}
\hline \multicolumn{3}{|c|}{ Table 2a: Structure of respondents by age } \\
\hline \multirow{4}{*}{} & Age & $\mathrm{f}$ & $\%$ \\
\hline & Younger than 30 years & & 12.5 \\
\hline & 31-40 years & & 26.8 \\
\hline & $41-50$ years & & 29.5 \\
\hline & $51-60$ years & & 29.5 \\
\hline & Older than 60 years & 1 & \\
\hline \multirow{4}{*}{ Missing } & Total & 111 & 100 \\
\hline Total & & 1 & \\
\hline Legend: $\mathrm{f}-$ frequency, \% - percent & 112 & 100 \\
\hline
\end{tabular}

In the first step we performed a factor analysis which showed inadequate structure, $\chi 2(347)=809.45, p<$ 0.001 . Also, a comparison between the selected and the base model showed that the selected model does not fit the data better than the basic model. The value of the selected parameters should be above $0.90, \mathrm{CFI}=$ $0.79, \mathrm{TLI}=0.77$. Based on these results, we concluded that the original factors were not suitable and an exploratory analysis of the main components was carried out for the new determination of factors. The results of 


\begin{tabular}{|c|c|c|c|c|c|c|}
\hline & & $\begin{array}{l}\mathrm{HCC} \\
\mathrm{LJ}\end{array}$ & $\begin{array}{l}\mathrm{HCC} \\
\mathrm{MB}\end{array}$ & $\begin{array}{l}\mathrm{HCC} \\
\mathrm{KR}\end{array}$ & $\begin{array}{c}\mathrm{HCC} \\
\mathrm{IZ}\end{array}$ & Total \\
\hline \multirow{3}{*}{$\begin{array}{l}\text { Gender } \\
\text { Total (n) }\end{array}$} & \multirow{3}{*}{$\begin{array}{c}\text { Male } \\
\text { Female }\end{array}$} & 1 & 4 & 2 & 3 & \\
\hline & & 38 & 34 & 13 & 16 & \\
\hline & & $n=41$ & $n=38$ & $n=15$ & $n=19$ & $\mathrm{n}=111$ \\
\hline \multirow{5}{*}{ Years } & Younger than 30 years & 4 & 4 & 2 & 4 & \\
\hline & $31-40$ years & 10 & 12 & 5 & 3 & \\
\hline & 41 - 50 years & 10 & 11 & 6 & 6 & \\
\hline & $51-60$ years & 14 & 11 & 2 & 6 & \\
\hline & Older than 60 years & 1 & 0 & 0 & 0 & \\
\hline Total (n) & & $n=39$ & $n=38$ & $n=15$ & $n=19$ & $\mathrm{n}=111$ \\
\hline
\end{tabular}

the preliminary $\mathrm{KMO}$ and Bartlett test showed that the sample is sufficiently compact and that the satisfactory number of correlations between items is different from zero, $\chi 2(378)=2318.32, p<0.001$. Based on the Kaiser-

\begin{tabular}{|c|c|c|c|c|}
\hline & \multicolumn{3}{|c|}{ Components } & \multirow{2}{*}{ Communalities } \\
\hline & 1 & 2 & 3 & \\
\hline vpr_trd1 & 0.98 & & & 0.69 \\
\hline vpr_trd2 & 0.91 & & & 0.68 \\
\hline vpr_trd9 & 0.88 & & & 0.66 \\
\hline vpr_trd12 & 0.81 & & & 0.62 \\
\hline vpr_trd7 & 0.79 & & & 0.58 \\
\hline vpr_trd14 & 0.78 & & & 0.50 \\
\hline vpr_trd8 & 0.73 & & & 0.44 \\
\hline vpr_trd13 & 0.72 & & & 0.65 \\
\hline vpr_trd15 & 0.64 & & & 0.48 \\
\hline vpr_trd27 & 0.62 & & & 0.74 \\
\hline vpr_trd22 & 0.59 & & & 0.60 \\
\hline vpr_trd18 & 0.56 & & & 0.57 \\
\hline vpr_trd24 & 0.53 & & & 0.66 \\
\hline vpr_trd11 & 0.51 & & & 0.62 \\
\hline vpr_trd4 & 0.49 & & & 0.50 \\
\hline vpr_trd21 & 0.49 & & & 0.61 \\
\hline
\end{tabular}

Guttman criterion, four components retained their own value over one and together explain $66.00 \%$ of the total variance. If we take into account Catell's criterion, we would retain two components, since the point of failure

\begin{tabular}{|c|c|c|c|c|}
\hline $\begin{array}{c}\text { Table 3a. Saturation of individual } \\
\text { components, utilities, components' own } \\
\text { values, and internal reliability of each } \\
\text { component }\end{array}$ \\
\hline & \multicolumn{3}{|c|}{ Components } & Communalities \\
\hline & 1 & 2 & 3 & \\
\hline & & 0.97 & & 0.64 \\
\hline vpr_trd26 & & 0.84 & 0.57 \\
\hline vpr_trd19 & & 0.69 & 0.72 \\
\hline vpr_trd28 & & 0.69 & & 0.72 \\
\hline vpr_trd20 & & 0.60 & & 0.65 \\
\hline vpr_trd17 & & 0.52 & & 0.68 \\
\hline vpr_trd23 & & & 0.83 & 0.63 \\
\hline vpr_trd16 & & 0.83 & 0.76 \\
\hline vpr_trd10 & & & 0.83 & 0.63 \\
\hline vpr_trd6 & & & 0.79 & 0.57 \\
\hline vpr_trd3 & & & 0.78 & 0.71 \\
\hline vpr_trd5 & & & 0.63 & 0.52 \\
\hline vpr_trd25 & & 2.51 & 1.29 & \\
\hline$\lambda$ & 13.58 & & \\
\hline \% variance & 48.51 & 8.95 & 4.59 & \\
\hline$\alpha$ & 0.95 & 0.89 & 0.88 & \\
\hline Legend: $\lambda=$ the value of each component, $\alpha=$ Cronbach \\
coefficient for the internal reliability of each component.
\end{tabular}


between the second and third component is the largest. Regarding to the distribution of items by components and previous research, we decided to keep three components that together explain $62.05 \%$ of the total variance. For improved interpretability, the Promax rotation was used as the components correlated highly with each other. All the items saturate components higher than the selected limit $r=0.45$, and all the items have a utility of 0.44 or higher, which means that the combination of all three components explains the individual variable. The average communality is 0.62 , which is also satis- factory. Based on these results, we decided to keep all items. Components were named according to previous studies, namely Component 1 as Transformation Leadership, Component 2 as Transactional Leadership and Component 3 as Laissez-faire Leadership (Table 3a-h).

On average, employees agreed that the introduced changes were successful, and employees, also estimate that leaders often use the leadership styles effectively. A low standard deviation suggests that employee responses were homogeneous and that most employees had positively assessed both efficiency and satisfac-

\begin{tabular}{|c|c|c|c|c|}
\hline \multicolumn{2}{|c|}{ Table 3b: Cronbach $\alpha$ coefficient for the variable of the transformational leadership } \\
\hline & $\begin{array}{c}\text { Scale Mean if Item } \\
\text { Deleted }\end{array}$ & $\begin{array}{c}\text { Scale Variance if } \\
\text { Item Deleted }\end{array}$ & $\begin{array}{c}\text { Corrected Item- } \\
\text { Total Correlation }\end{array}$ & $\begin{array}{c}\text { Cronbach's Alpha if } \\
\text { Item Deleted }\end{array}$ \\
\hline vpr_trd1 & 41.05 & 150.970 & 0.748 & 0.948 \\
\hline vpr_trd2 & 41.24 & 151.770 & 0.771 & 0.947 \\
\hline vpr_trd9 & 41.33 & 148.728 & 0.762 & 0.947 \\
\hline vpr_trd12 & 41.35 & 151.166 & 0.741 & 0.948 \\
\hline vpr_trd14 & 41.89 & 151.790 & 0.652 & 0.950 \\
\hline vpr_trd7 & 41.13 & 152.435 & 0.710 & 0.948 \\
\hline vpr_trd8 & 41.11 & 156.169 & 0.613 & 0.950 \\
\hline vpr_trd13 & 41.47 & 151.909 & 0.770 & 0.947 \\
\hline vpr_trd15 & 41.34 & 153.289 & 0.660 & 0.949 \\
\hline vpr_trd27 & 41.19 & 149.271 & 0.818 & 0.946 \\
\hline vpr_trd22 & 41.54 & 151.368 & 0.724 & 0.948 \\
\hline vpr_trd18 & 41.21 & 153.966 & 0.717 & 0.948 \\
\hline vpr_trd24 & 41.45 & 151.925 & 0.771 & 0.947 \\
\hline vpr_trd11 & 41.21 & 151.395 & 0.746 & 0.948 \\
\hline vpr_trd4 & 41.12 & 156.734 & 0.632 & 0.950 \\
\hline vpr_trd21 & 41.32 & 152.707 & 0.728 & 0.948 \\
\hline Legend: $\alpha$ =0.951, N of Items $=16$ & & & & \\
\hline
\end{tabular}

\section{Table 3c: Cronbach $\alpha$ coefficient for the variable of the transactional leadership}

\begin{tabular}{|c|c|c|c|c|}
\hline \multicolumn{5}{|c|}{ Item-Total Statistics } \\
\hline & $\begin{array}{c}\text { Scale Mean if Item } \\
\text { Deleted }\end{array}$ & $\begin{array}{c}\text { Scale Variance if } \\
\text { Item Deleted }\end{array}$ & $\begin{array}{c}\text { Corrected Item- } \\
\text { Total Correlation }\end{array}$ & $\begin{array}{c}\text { Cronbach's Alpha if } \\
\text { Item Deleted }\end{array}$ \\
\hline vpr_trd26 & 14.29 & 17.990 & 0.589 & 0.884 \\
\hline vpr_trd19 & 14.16 & 17.920 & 0.646 & 0.875 \\
\hline vpr_trd28 & 14.21 & 16.584 & 0.749 & 0.858 \\
\hline vpr_trd20 & 14.10 & 16.270 & 0.783 & 0.852 \\
\hline vpr_trd17 & 13.95 & 17.619 & 0.710 & 0.865 \\
\hline vpr_trd23 & 14.43 & 16.698 & 0.726 & 0.862 \\
\hline Legend: $\alpha=0.886, N$ of Items $=6$ & & & & \\
\hline
\end{tabular}




\section{Table 3d: Cronbach $\alpha$ coefficient for the variable of the laissez-faire leadership}

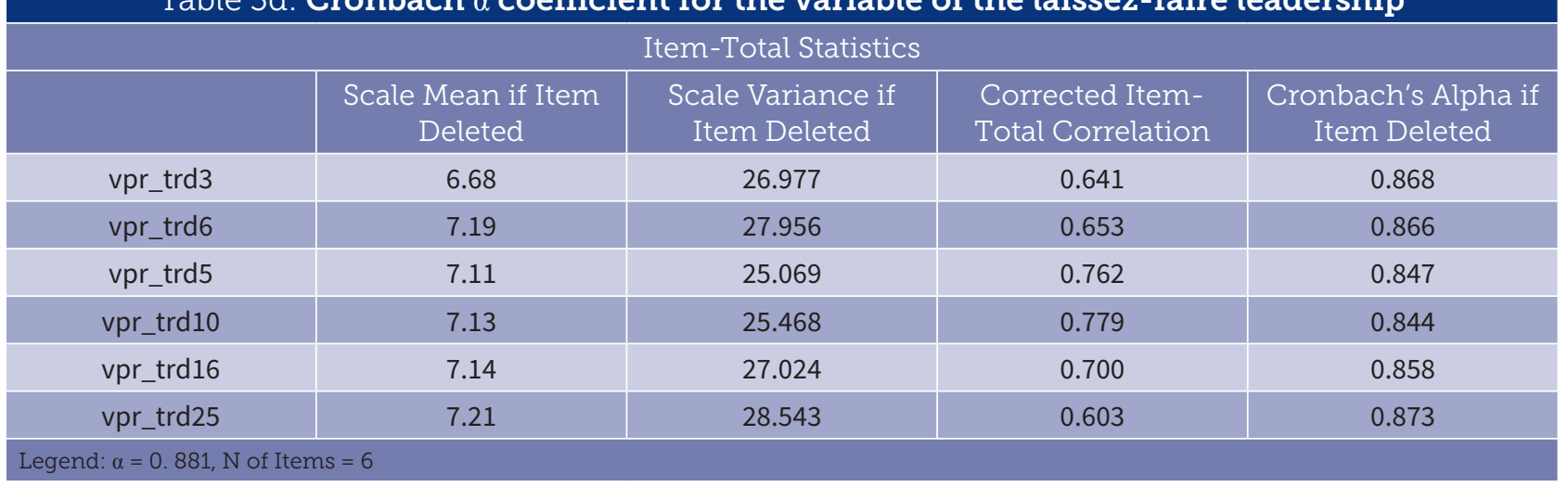

Table 3e: Cronbach $\alpha$ coefficient for the variable of style management effectiveness

Item-Total Statistics

\begin{tabular}{|c|c|c|c|c|}
\hline & $\begin{array}{c}\text { Scale Mean if Item } \\
\text { Deleted }\end{array}$ & $\begin{array}{c}\text { Scale Variance if } \\
\text { Item Deleted }\end{array}$ & $\begin{array}{c}\text { Corrected Item- } \\
\text { Total Correlation }\end{array}$ & $\begin{array}{c}\text { Cronbach's Alpha if } \\
\text { Item Deleted }\end{array}$ \\
\hline Q5a & 11.125 & 6.182 & 0.780 & 0.898 \\
\hline Q5b & 11.223 & 6.193 & 0.738 & 0.912 \\
\hline Q5c & 11.223 & 5.598 & 0.862 & 0.869 \\
\hline Q5d & 11.241 & 5.554 & 0.844 & 0.875 \\
\hline Legend: $\alpha=0.916, \mathrm{~N}$ of Items $=4$ & & & & \\
\hline
\end{tabular}

Table 3f: Cronbach $\alpha$ coefficient for the variable of style management effectiveness

Item-Total Statistics

\begin{tabular}{|c|c|c|c|c|}
\hline & $\begin{array}{c}\text { Scale Mean if Item } \\
\text { Deleted }\end{array}$ & $\begin{array}{c}\text { Scale Variance if } \\
\text { Item Deleted }\end{array}$ & $\begin{array}{c}\text { Corrected Item- } \\
\text { Total Correlation }\end{array}$ & $\begin{array}{c}\text { Cronbach's Alpha if } \\
\text { Item Deleted }\end{array}$ \\
\hline Q3a & 7.964 & 2.773 & 0.782 & 0.750 \\
\hline Q3b & 7.714 & 3.665 & 0.723 & 0.833 \\
\hline Q3c & 7.964 & 2.575 & 0.740 & 0.808 \\
\hline Legend: $\alpha=0.857, \mathrm{~N}$ of Items $=3$ & & &
\end{tabular}

Table 3g: Descriptive statistics of the effectiveness of the introduced changes, the effectiveness of leadership styles and satisfaction with the management styles used

\begin{tabular}{|c|c|c|c|}
\hline & $\begin{array}{c}\text { Effectiveness of the } \\
\text { introduced changes }\end{array}$ & $\begin{array}{c}\text { Effectiveness of } \\
\text { leadership styles }\end{array}$ & $\begin{array}{c}\text { Satisfaction with the } \\
\text { management style used }\end{array}$ \\
\hline M & 3.73 & 2.94 & 2.91 \\
\hline SD & 0.80 & 0.84 & 0.99 \\
\hline Variance & 0.64 & 0.70 & 0.97 \\
\hline Asymmetry & -0.62 & -0.51 & -0.66 \\
\hline Kurtosis & 0.66 & -0.45 & -0.34 \\
\hline Min & 1.00 & 0.67 & 0.00 \\
\hline Max & 5.00 & 4.00 & 4.00 \\
\hline$D(112)$ & 0.14 & 0.14 & 0.18 \\
\hline P & $<0.001$ & $<0.001$ & $<0.001$ \\
\hline
\end{tabular}


tion with management styles. Based on negative asymmetries in all three variables, we can also appreciate that the majority of employees have positively assessed both the performance of the introduced changes and the effectiveness of leadership styles, and satisfaction with the changes introduced (Table 3g). Based on KolmogorovSmirnovega test we performed a parametric analysis.

\begin{tabular}{|c|c|c|c|}
\hline & $\mathrm{TF}$ & TS & LF \\
\hline$M$ & 2.75 & 2.84 & 1.42 \\
\hline SD & 0.82 & 0.82 & 1.02 \\
\hline Variance & 0.67 & 0.67 & 1.05 \\
\hline Asymmetry & -0.75 & -0.70 & 0.35 \\
\hline Kurtosis & 0.07 & 0.29 & -0.94 \\
\hline Min & 0.25 & 0.33 & 0.00 \\
\hline Max & 4.00 & 4.00 & 3.83 \\
\hline$D(112)$ & 0.12 & 0.09 & 0.11 \\
\hline$P$ & 0.001 & 0.016 & 0.004 \\
\hline \multicolumn{4}{|c|}{$\begin{array}{l}\text { Legend: } \mathrm{TF} \text { - transformational leadership, TS - transactional } \\
\text { leadership, } \mathrm{LF} \text { - laissez-faire leadership, } \mathrm{M}=\text { mean, } \mathrm{SD}=\text { standard } \\
\text { deviation, Min = minimum, Max = maximum, D = Kolmogorov- } \\
\text { Smirnov test, } \mathrm{p}=\text { level of statistical significance }\end{array}$} \\
\hline
\end{tabular}

Employees estimated that managers were using the same transactional and transformational management as often as they used, and least often laissez-faire (passive) management, with least uniform answers being exactly in the last style of management. From positive asymmetries in passive management, it is also evident that employees were more likely to evaluate the abovementioned management with lower estimates, i.e. the given behavior associated with this management description was not evaluated as frequent (Table $3 \mathrm{~h}$ ).

Table 4 shows that the success of the introduced changes is statistically significant $(p<0.05)$ and associated with all three types of leadership. The link between transformational and transactional leadership and the effectiveness of the introduced changes is highly positive, but the strength of the connection between the effectiveness of the introduced changes and the transformational leadership is higher than the strength of the connection between the effectiveness of the introduced changes and the transactional leadership. The more employees perceive the introduced changes as successful, the more managers use transformational and transactional leadership, and vice versa. However, employees evaluated the effectiveness of the introduced changes higher if the transformational and transactional leadership were used. Based on the interpretation of the results we can confirm the $\mathrm{H} 1$ and $\mathrm{H} 2$.

There is a medium strong negative correlation between laissez-faire leadership and the effectiveness of the introduced changes, which means that more employees perceive the introduced changes as successful, the less managers use laissez-faire guidance and vice versa. Based on the interpretation of the results we can confirm the H3.

There is a statistically significant $(p<0.05)$ relationship between the estimated effectiveness of leadership and all three types of leadership (Table 5). Transformational

\section{Table 4: Correlation coefficients between effectiveness and leadership}

\begin{tabular}{|c|c|c|c|}
\hline & {$[1]$} & {$[2]$} & {$[3]$} \\
\hline 1. TF & - & & \\
\hline 2. TS & $.81^{* *}$ & - & - \\
\hline 3. LF & $-.53^{* *}$ & $-.50^{* *}$ & $.59^{* *}$ \\
\hline 4. Effectiveness of the introduced changes & $.65^{* *}$ & $-.40^{* *}$ \\
\hline Legend: TF - transformational leadership, TS - transactional leadership, LF - laissez-faire leadership, ** $=0,01$.
\end{tabular}

Table 5: Connection of all three leadership types with effectiveness estimation

\begin{tabular}{|c|c|c|c|c|}
\hline \multicolumn{4}{|c|}{ Table 5: Connection of all three leadership types with effectiveness estimation } \\
\hline & {$[1]$} & {$[2]$} & {$[3]$} \\
\hline 1. TF & - & - & - \\
\hline 2. TS & $.81^{* *}$ & $-.50^{* *}$ & $.74^{* *}$ & $-.46^{* *}$ \\
\hline 3. LF & $-.53^{* *}$ & $.84^{* *}$ & - \\
\hline 4. Effectiveness of leadership & [3] & -01. \\
\hline
\end{tabular}


and transactional leadership are strongly influenced by the estimated effectiveness of leadership styles, while the laissez-faire leadership has a medium strong negative correlation. The results indicate that, the more employees estimate that used leadership style was effective, the more managers used transformational and transactional leadership, and laissez-faire leadership less and vice versa. Based on the interpretation of the results we can confirm the $\mathrm{H} 4$ (Table 6). Results show greater affection of employees towards transformational leadership.

Transformational and transactional leadership are strongly positively linked with the introduced changes, while laissez-faire leadership is moderately strong negative. With employees who are satisfied with the changes that have been introduced, managers used transformational and transactional leadership more, and laissez-faire leadership less and vice versa. Based on the interpretation of the results we can confirm the $\mathrm{H} 5$.

\section{Discussion}

crs?

Organizations are social systems where human resources play the most important role in their success and smooth functioning ${ }^{77,116}$. Employee satisfaction is often seen as the employee's attitude towards their jobs and organizations ${ }^{116}$.

A number of the healthcare literature point out that there is a link between the management and the employee's satisfaction in healthcare organizations ${ }^{110,117-119}$. Among the satisfaction factors, leadership has recently been seen as an important predictor. In particular, researchers acknowledge the importance of transformational guidance in enhancing employee satisfaction in healthcare organizations ${ }^{120-123}$, since healthcare professionals often work in high-pressure environments.

This connection between transformational guidance and employee satisfaction is well established in the current literature ${ }^{124-126}$. In conjunction with today's dynamic business environment, transformational leaders are often considered to be the ideal change managers who could lead their employees in uncertainty and highrisk positions ${ }^{127}$. There is a wide range of management styles presented in the extensive literature that could influence the satisfaction and commitment of employees, but transformational leadership is set in the foreground with its supportive, productive and innovative nature ${ }^{128,129,130}$.

Andrews and Dziegielewski ${ }^{122}$ explain in their work that staff in healthcare organizations favour managers who use a transformational management approach since they only treat employees and their needs completely individually. This study supports the results of the remaining studies ${ }^{131,132}$, which highlight a statistically significant positive link between transformational guidance and employee satisfaction, contributing to higher organizational performance and employee readiness ${ }^{124}$. This can be explained by the fact that such leaders increase employee expectations, recognize their work, increase satisfaction with individual attention, intellectual stimulation and motivation. In addition, the participative decision-making process gives a sense of involvement to employees ${ }^{133-134}$.

Before the introduction of transformational management, the transactional style was perceived as being the most effective in healthcare organizations ${ }^{136}$. The study's findings ${ }^{137}$ showed that laissez-faire management is the least effective form of conduct of the leader and, also, negatively linked to satisfaction ${ }^{138}$.

\begin{tabular}{|c|c|c|c|c|}
\hline & [1] & [2] & [3] & [4] \\
\hline 1. TF & - & & & \\
\hline 2. TS & $.81^{* *}$ & - & & \\
\hline 3. LF & $-.53^{* *}$ & $-.50^{* *}$ & - & \\
\hline 4. Satisfaction with the introduced changes & $.83^{* *}$ & $.74^{* *}$ & $-.44^{* *}$ & - \\
\hline
\end{tabular}




\section{Conclusions and recommendations}

We are faced with a constant in a constantly changing business environment. These changes represent the cause, fact and condition for the organizational survival, and are at the same time of special interest for researchers who aim at designing new and more appropriate methods for managing change. The effective functioning of healthcare organizations is based on appropriate leadership, and transformational leadership is often associated with greater efficiency and positive organizational results, and consequently achieves a higher success rate of change. Managers with this type of leadership style are powerful change agents and visionary individuals, who have many skills and believe in people ${ }^{139}$. It is necessary to emphasize primarily the leadership of radical, major changes, which in organizations rarely occur as incremental, gradual changes because they are more risky and have a greater impact on the success of healthcare organizations.

Worrying, however, not surprising, is the information that only $30 \%$ of initiated changes succeed. The introduction of new organizational changes is not supported by leaders $(33 \%)$ and $39 \%$ of employees ${ }^{23}$. The performed quantitative study showed that in the healthcare centers frequently used incremental changes and minor changes as a radical intervention. A greater chance for successful introduction of changes is guaranteed by the transformational leadership. Employees defined transformational and transactional leadership as the most effective.

Research limitation: data were collected within a specific period of time and are representative of the period of the study.

\section{References}

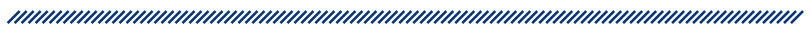

1. Kovač J, Mayer J, Jesenko M. Stili in značilnosti uspešnega vodenja. Kranj: Moderna organizacija, 2004

2. Johns H, Moser HR. From trait to transformation: the evolution of leadership theories. Education. 1989; 110(1), 115122.
3. Bass BM. From transactional to transformational leadership: learning to share the vision. Organ Dyn. 1990; 18(3):19-31.

4. Appelbaum SH, Degbe MC, MacDonald O, Nguyen-Quang T. Organizational outcomes of leadership style and resistance to change (part one). Industrial and Commercial Training. 2015; 47(2): 73-80.

5. Batool FB. Emotional intelligence and effective leadership. J Bus Stud Q. 2013; 4(3): 84-94.

6. Kovač J, Mühlbacher J, Kodydek G. Uvod v management sprememb. Kranj: Moderna organizacija v okviru Fakultete za organizacijske vede, 2012.

7. Yukl G. Leadership in organizations. New Delhi: Dorling Kindersley, 2011.

8. Northouse PG. Leadership: theory and practice. $6^{\text {th }}$ ed.CA: Sage, 2013.

9. Sellgren S, Ekvall R, Tomson R. Leadership styles in nursing management: preferred and perceived. J Nurs Manag. 2006; 14(5): 348-355.

10. Steinmann H, Schreyögg G. Management. Wiesbaden: Gabler, 2005.

11. Hitt MA, Black JS, Porter LW. Management. New York: Upper Saddle River, 2009.

12. Williams C. Principles of management. Mason: SouthWestern Cengage Learnig, 2009.

13. Daft RL. New era of management. Mason: South-Western Cengage Learnig, 2010.

14. Mayer J. Lastnosti uspešnih vodij. Organizacija. 2003; 36(6): 268-275.

15. Možina S, Rozman R, Tavčar M, Pučko D, Ivanko Š, Lipičnik B et al. Management: nova znanja za uspeh. Radovljica: Didakta, 2002.

16. Miller P. Strategy and the ethical management of human resources. Hum Resource Manag J. 1996; 6(1): 5-17.

17. Kovačič $H$, Rus A. Leadership competences in Slovenian health care. Zdrav var. 2015; 54(1): 11-17.

18. Townsend K, Wilkinson A, Bamber G, Allan C. Accidental, unprepared, and unsupported: clinical nurses becoming managers. International Journal of Human Resource Management. 2012; 23(1): 204-220.

19. Pillay R. The skills gap in hospital management in the South African public health sector. Journal of Public Health Management Practice. 2008; 14(5): E8-E14.

20. McCallin, A.M. and Frankson, C. (2010), "The role of the charge nurse manager: a descriptive exploratory study". J Nurs Manag. 201; 18(3): 319-325.

21. Northouse PG. Leadership: theory and practice. $2^{\text {nd }}$ ed. London: Sage Publications, 2001.

22. Paton RA, McCalman J. Change management: a guide to effective implementation. $3^{\text {rd }}$ edition. London: Sage Publications, 2010.

23. Longenecker CO, Longenecker PD. Why hospital improvement efforts fail: a view from the front line. J Healthc Mnag. 2014; 59(2): 147-157.

24. Lee V, Ridzi F, Lo AW, Coskun E. A healthcare case study of team learner style and change management. J Organ Change Manag. 2011; 24(6): 830-852. 
25. Evans R, Russell P. Ustvarjalni manager: senzacionalna knjiga o osebni moči. Ljubljana: Alpha center, 1992.

26. Gilley A, McMillan HS, Gilley JW. Organizational change and characteristics of leadership effectiveness. JLOS. 2009; 16(1): 38-47.

27. Robbins SP, Coulter M. Management. New York: PracticeHall, 2009.

28. Robbins SP, Judge T. Organizational Behavior. New York: Practice-Hal, 2009.

29. Mayo A. Forever Change. Training Journal. 2002; 40.

30. Quinn RE. Building the bridge as you walk on it. San Francisco: Jossey-Bass, 2004.

31. Norton B. Being a leader through times of change. Clinicial in Management. 2015; 15:115-118.

32. Mauer R. Why do so many changes still fail (part two). The Journal for Quality and Participation. 2011; 33(4):33-34.

33. Arnett G. Cost reduction in health systems: mission critical. Frontiers of Health Services Management. 2010; 27(2):37-40.

34. Bukovec B. Pomen voditeljstva v procesu obvladovanja sprememb. Organizacija. 2005; 38(1): 39-45. Kranj: Moderna organizacija.

35. Martin JS, McCormack B, Fitzsimons D, Spirig R. Evaluation of leadership practices: how to develop a vision. J Res Nurs. 2014; 19(2): 102-115.

36. Louis C, Ulrich D, Goldsmith M. Best Practices in leadership development and organization change: how the best companies ensure meaningful change and sustainable leadership. San Francisco: Pfeifer, 2004.

37. Cork A. A model for successful change management. Nurs Stand. 2005; 19(25): 40-42.

38. Higgs MJ. Developments in leadership thinking. Journal of Organisational Development and Leadership. 2003; 24(5): 273-284.

39. Higgs MJ, Rowland D. Emperors with clothes on: the role of self-awareness in developing effective change leadership. J Change Manag. 2010; 10(4): 369-385.

40. Kotter J. A force for change: how leadership differs from management. New York: Simon \& Schuster, 1990.

41. Higgs MJ, Rowland D. Building change leadership capability: the quest for change competence. J Change Manag. 2000; 1(2), 116-131.

42. Herold DM, Fedor DB in Caldwell S. The effects of transformational and change leadership on employees' commitment to a change: a multilevel study. J Appl Psychol. 2008; 93(2):346-357.

43. Metre C. Deriving value from change management. Journal of Science in Organisational Dynamics. 2009; 1(1):1-47.

44. Viens C, Lavoie-Tremblay M, Leclerc MM, Brabant LH. New approaches of organizing care and work: giving way to participation, mobilization, and innovation. Health Care Manag. 2005; 24(2): 150-158.

45. Fagerström L, Salmela S. Leading change: a challenge for leaders in Nordic health care - J Nurs Manag. 2010; 18(5): 613-617.
46. Beaman KV, Guy GR. Effecting Change in Business Enterprises: Current Trends in Change Management. New York, The Conference Board, 2005.

47. Beer M, Nohria N. Breaking the code of change. Boston: Harvard Business School Press, 2000.

48. Al-Hussami M, Hamad S, Darawad M, Maharmeh M. The effects of leadership competencies and quality of work on the perceived readiness for organizational change among nurse managers. Leader Health Serv. 2017; 30(4): 443-456.

49. Appelbaum SH, Cameron A, Ensink F, Hazarika J, Attir R, Ezzedine R, Shekhar V. Factors that impact the success of an organizational change: a case study analysis. Ind Commerc Train. 2017; 49(5): 213-230.

50. Griffith-Cooper B, King K. The partnership between project management and organisational change: integrating change management with change leadership. Perform Improv. 2007; 46(1):14.

51. Hamstra MRW, Yperen NWV, Wisse B, Sassenberg K. Transformational transactional leadership styles and followers regulatory focus. J Pers Psychol. 2011; 10(4): 82-86.

52. Li M, Liu W, Han Y, Zhang P. Linking empowering leadership and change-oriented organizational citizenship behavior: the role of thriving at work and autonomy orientation. J Organ Change Manag. 2016; 29(5): 732-750.

53. Bass BM, Riggio RE. Transformational leadership. Mahwah, NJ: Erlbaum, 2006.

54. Higgs MJ, Rowland D. All changes great and small: exploring approaches to change and its leadership. J Change Manag. 2005; 5(2): 121-151.

55. Nazim A, Shahid A, Anjum A, Wali R, Shahid J. Effects of leadership styles on job satisfaction, organizational citizenship behaviour, commitment and turn over intention (empirical study of private sector schools' teachers). Journal of life science. 2014; 11(3): 175-183.

56. Khatoon S, Farooq A. Employee's attitude toward change and organizational performance. International Journal for Research in Emerging Science and Technology. 2015; 2(5): 54-61.

57. Harvey TR. Checklist for change: a pragmatic approach to creating and controlling change. Second edition. Lancaster PA: Technomic Publishing Inc, 1995.

58. Daft RL. Management. $5^{\text {th }}$ ed. Fort Worth PA, The Dryden Press, 2000.

59. Greif S, Runde B, Seeberg I. Erfolgsfaktoren beim Change Management in acht Ländern. Wirtschaftspsychologie aktuell. 2005; 3(1):22-26.

60. Jones RA, Jimmieson NL, Griffiths A. The impact of organizational culture and reshaping capabilities on change implementation success: the mediating role of readiness for change. J Manag Stud. 2005; 42(2): 361-386.

61. Wanber CR, Banas JT. Predictors and outcomes of openness to changes in a reorganizing workplace. J Appl Psychol. 2000; 85(1): 132-142.

62. Miller VD, Johnson JR, Grau J. Antecedents to willingness to participate in a planned organizational change. J Appl Commun Res. 1994; 22(1): 59-80. 
63. Armenakis AA, Harris SG, Mossholder KW. Creating readiness for organizational change. Hum Relat. 1993; 46(6): 681-703.

64. Choi M. Employees' attitudes toward organizational change: A literature review. Hum Resource Manag. 2011; 50(4): 479-500.

65. Christl B, Harris MF, Jayasinghe UW, Proudfoot J, Taggart J, Tan J..Readiness for organisational change among general practice staff. Qual Saf Health Care. 2010; 19:12-16.

66. Eby LT, Adams DM, Russell JEA, Gaby SH. Perceptions of organizational readiness for change: factors related to employees' reactions to the implementation of teambased selling. Human Relations. 2000; 53(3): 419-442.

67. Kubr M. Management consulting: a guide to the profession. $3^{\text {rd }}$ ed. Geneva: International Labour Office, 1996.

68. Mosadeghrad AM. Obstacles to TQM success in health care systems. Int J Health Care Qual Assur. 2013; 26(2):147-173.

69. Mayfield S. Improving organizational performance. H\&HN. 2006: 30-34.

70. Fedor DB, Caldwell S, Herold DM. The effects of organizational changes on employee commitment: a multilevel investigation. Pers Psychol. 2006; 56(1): 1-29.

71. Copnell B, Bruni N. Breaking the silence: nurses' understandings of change in clinical practice. J Adv Nurs . 2006; 55(3): 301-309.

72. Balfour M, Clarke C. Searching for sustainable change. J Clin Nurs. 2001; 10(1), 44-50.

73. Brandao de Souza L, Pidd M. Exploring the barriers to lean health care implementation. Public Money Manage. 2011; 31(1): 59-66.

74. Filej B. Organizacijsko spreminjanje v zdravstveni negi je odvisno od vsake posamezne glavne medicinske sestre zdravstvenih in socialnovarstvenih zavodov. Obzor Zdrav Neg. 2009; 43(1): 3-11.

75. Dahlgaard JJ, Pettersen J, Dahlgaard-Park SM. Quality and lean healthcare: a system for assessing and improving the health of healthcare organizations. Total Qual Manag. 2011; 22(6): 673-689.

76. Adler PS, Riley P, Kwon SW, Signer JK, Lee B, Satrasala R. Performance improvement capability: keys to accelerating performance improvement in hospitals. Calif Manage Rev. 2003; 45(2):12-33.

77. Mosadeghrad AM. Principles of health care administration.Tehran: Dibagran Tehran, 2003.

78. Chassin MR. Improving the quality of health care: what's taking so long? Health Aff. 2013; 32(10): 1761-1765.

79. Skela Savič. Ali so potrebne spremembe na področju vodenja zaposlenih v zdravstvu? In Skela Savič B, Kavčič BM eds. Vodenje, motivacija in čustvena inteligenca vodje v zdravstvu: zbornik predavanj z recenzijo. Bled, 16. april 2008. Jesenice: Visoka šola za zdravstveno nego, 2008.

80. Mankins MC, Steele R. Turning great strategy into great performance. Harvard Bus Rev. 2005; 83(8): 64-72.

81. Sull DN. Closing the gap between strategy and execution. Manag Rev. 2007; 48(4): 30-38.
82. Mrkaić M, Pezdir R. Omejitve poslovanja bolnišnic: korenine neučinkovitosti slovenskega zdravstva. Bilten: ekonomika, organizacija, informatika v zdravstvu. 2007; 23(4).

83. Skela Savič B. Dejavniki uspešnega uvajanja sprememb. In Pezdirc MS eds. Management v zdravstvu. Ljubljana: GV izobraževanje, 2005.

84. Spehar I, Sjøvik H, Karevold KI, Olaug Rosvold E, Frich JC. General practitioners' views on leadership roles and challenges in primary health care: a qualitative study. Scand J Prim Health Care. 2017; 35(1): 105-110.

85. Liu Y. When change leadership impacts commitment to change and when it doesn't. A multi-level multi-dimensional investigation. PhD diss. Georgia Institute of Technology, 2010.

86. Sullivan W, Sullivan R, Buffton B. Aligning individual and organizational values to support change. J Cgange Manag. 2002; 2(3): 247-254.

87. Van Rossum L, Aij KH, Simons FE, Van der Eng N, Dirk ten Have W. Lean healthcare from a change management perspective: the role of leadership and workforce flexibility in an operating theatre. J Health Organisat Manag. 2016; 30(3): 475-493.

88. Lindholm M, Sivberg, B,Ude AG. Leadership styles among nurse managers in changing organizations. J Nurs Manag. 2000; 8(2): 327-335.

89. Kaplan GS, Patterson SH, Ching JM, Blackmore CC. Why Lean doesn't work for everyone. BMJ Qual Saf. 2014; 23(12):970-973.

90. Shao L, Webber S. A cross-cultural test of the five-factor model of personality and transformational leadership. J BUS RES. 2006; 59: 936-944.

91. Steed A. An exploration of the leadership attributes and methods associated with successful lean system deployments in acute care hospitals. Qual Manag Health Care. 2012; 21(1): 48-58.

92. Mann D. The missing link: lean leadership. Frontiers of Health Services Management 2009; 26(1):15-26.

93. Jimmerson C, Weber D, Sobek DK. Reducing waste and errors: piloting lean principles at Intermountain Healthcare. Joint Comm J Qual Patient Saf. 2005; 31(5): 249-257.

94. Womack JP, Byrne AP, Flume OJ, Kaplan GS, Toussaint J. Going lean in health care - Institute for healthcare improvement. Boston: MA, 2005.

95. Bowen DJ. 5 Competencies for CEOs. Trustee. 2015; 34-39.

96. Bass BM. Leadership and performance beyond expectations. New York: Free Press, 1985.

97. Martinez-Gonzalez M, Monreal-Bosch P, Perera S, Olid CS. Public healthcare organizations: leadership or management. Athenea Digital. 2016; 16(3): 245-257.

98. Van der Voet J, Kuipers BS, Groeneveld S. Implementing change in public organizations. The relationship between leadership and affective commitment to change in a public sector contex. Public Manag Rev. 2016; 18(6): 842-865.

99. Leong LYC, Fischer R. Is transformational leadership universal? A meta-analytical investigation of multifactor 
leadership questionnaire. J Leader Organ Stud. 2011; 18(2): 164-174.

100. Hernandez BJD. The relationship between leadership styles and performance success in hospitals. Walden University, 2010.

101. Flood PC, Hannan E, Smith KG, Turner T,West MA, Dawson J. Chief executive style, consensus decision making, and top management team effectiveness. Eur J Work Organ Psy. 2000; 9(3): 401-420.

102. Dawson P. Understanding organizational change: the contemporary experience of people at work. London: SAGE Publications, 2003.

103. Burke WW. Organization change: theory and practice. Los Angeles, CA: SAGE Publications, 2002.

104. Oreg S, Berson Y. Leadership and employees' reactions to change: the role of leaders' personal attributes and transformational leadership style. Pers Psychol. 2011; 64(3): 627-659.

105. Ilies R, Judge T, Wagner D. Making sense of motivational leadership: the trail from transformational leaders to motivated followers. J Leader Organ Stud. 2006; 13(1): 1-22.

106. Dvir T, Eden D, Avolio BJ, Shamir B. Impact of transformational leadership on follower development and performance: a field experiment. Acad Manage J. 2002; 45(4): 735-744.

107. Lo M, Ramayah T, Run E. Does transformational leadership style foster commitment to change? The case of higher education in Malaysia. Procedia-Social and Behavioral Sciences. 2010; 2(2): 5384-5388.

108. Antonakis J, Avolio BJ, Sivasubramaniam N. Context and leadership: an examination of the nine-factor full range leadership theory using the Multi Leadership Questionnaire. Leadership Quart. 2003; 14(3): 261-295.

109. Syndell MA. The role of emotional intelligence in transformational leadership style. Minneapolis: Cappella University, 2008.

110. Kleinman C. Leadership and retention: research needed. J Nurs Admin. 2004; 34(3): 111-113.

111. Bass BM, Avolio BJ, Jung DI, Berson Y. Predicting unit performance by assessing transformational and transactional leadership. J Appl Psychol. 2003; 88(2): 207-218.

112. Canty LT. Conceptual assessment: transformational, transactional and Laissez-Faire leadership styles and job performances of managers as perceived by their direct reports. Minneapolis: Capella University, 2015.

113. Cummings GG, MacGregor T, Davey M, Lee H, Wong CA, Lo E, Muise M, Stafford E. Leadership styles and outcome patterns for the nursing workforce and work environment: a systematic review. Int J Nurs Stud. 2010; 47(3): 363-385.

114. Martinčič R (2016). Stili vodenja v procesih spreminjanja: primer slovenskih bolnišnic. Doktorska disertacija. Univerza na Primorskem: Fakulteta za management.

115. Xirasagar S, Samuels ME, Stoskopf CH. Physician leadership and effectiveness: an empirical study. eEdical care research and review. 2005; 62(2): 720-740
116. Mosadeghrad AM, Yarmohammadian MH. A study of relationship between managers' leadership style and employees' job satisfaction. Leader Health Serv. 2006; 19(2);11-28.

117. Seo Y, Ko J, Price JL. The determinants of job satisfaction among hospital nurses: a model estimation in Korea. Int J Nurs Stud. 2004; 41(4): 437-446.

118. Vance C, Larson E. Leadership research in business and health care. J. Nurse Scholash. 2002; 34(2):165-171.

119. Berson Y, Linton JD. An examination of the relationships between leadership style, quality, and employee satisfaction in $R \& D$ versus administrative environments. $R \& D$ MANAGE. 2005; 35(1): 51-60.

120. Nielsen K, Yarker J, Randall R, Munir F. The mediating effects of team and self-efficacy on the relationship between transformational leadership, and job satisfaction and psychological well-being in healthcare professionals: a cross-sectional questionnaire survey. Int J Nurs Stud. 2009; 46(9):1236-1244.

121. Wang X, Chontawan R, Nantsupawat R. Transformational leadership: effect on the job satisfaction of registered nurses in a hospital in China. J Adv Nurs. 2012; 68(2): 444-451.

122. Andrews DR, Dziegielewski SF. The nurse manager: job satisfaction, the nursing shortage and retention. J Nurs Manag. 2005; 13(4): 286-295.

123. Luo Z, Fang P, Fang Z. What is the job satisfaction and active participation of medical staff in public hospital reform: a study in Hubei province of China. Hum Resour Health. 2015; 13(1): 34.

124. Walumbwa FO, Wang P, Lawler JJ, Shi K. The role of collective efficacy in the relations between transformational leadership and work outcomes. J Occup Organ Psychol. 2004; 77(4): 515-530.

125. Avolio BJ, Zhu W, Koh W, Bhatia P. Transformational leadership and organizational commitment: mediating role of psychological empowerment and moderating role of structural distance. J Organ Behav. 2004; 25(8):951-968.

126. Wright BE, Pandey SK. Transformational leadership in the public sector: does structure matter? J Public Adm Res Theory. 2010; 20(1):75-78.

127. Northouse PG. Leadership, theory and practice. $5^{\text {th }}$ ed. Sage, Thousand Oaks, CA, 2010.

128. Mesu J, Sanders K, Van Riemsdijk M. Transformational leadership and organisational commitment in manufacturing and service small to medium-sized enterprises The moderating effects of directive and participative leadership. Pers Rev. 2015; 44(6): 970-990.

129. Yahaya R, Ebrahim F. Leadership styles and organizational commitment: literature review. J Manag Dev. 2016; 35(2): 190-216.

130. Yucel I, McMillan A, Richard OC. Does CEO transformational leadership influence top executive normative commitment? J Bus Res. 2014; 67(6): 1170-1177.

131. Mohammad S, Al-Zeaud H, Batayneh, A. The relationship between transformational leadership and employees' 
satisfaction at Jordanian Private Hospitals. J Bus Econ Horiz. 2011; 5(2): 35-46.

132. Boamah SA, Spence Laschinger, HK, Wong C, Clarke S. Effect of transformational leadership on job satisfaction and patient safety outcomes. Nurs Outlook. 2017; 66(2):180-189.

133. Bass B, Avolio BJ. Developing transformational leadership. J Eur Ind Train. 1990; 14(5): 21-34.

134. Nemanich LA, Keller RT. Transformational leadership in an acquisition: a field study of employees. Leadersh $Q$. 2007; 18(1): 49-68.

135. Braun S, Peus C, Weisweiler S, Frey D. Transformational leadership, job satisfaction, and team performance: a multilevel mediation model of trust. Leadersh Q. 2013; 24(1): 270-283.
136. Huber DL. Leadership and nursing care management. $3^{\text {rd }}$ ed. Philadelphia, Elsevier Inc, 2006.

137. Khan M, Ramzan M, Ahmed I, Nawaz M. Transformational, transactional, and laissez-faire styles of teaching faculty as predictors of satisfaction, and extra effort among the students: evidence from higher education institutions. Interdisciplinary Journal of Research in Business. 2011; 1(4): 130-135.

138. Rowold J, Wolff S. Transformational and transactional leadership and followers' chronic stress. Leader Rev. 2009; 9: 35-48.

139. Hernandez BJD. The relationship between leadership styles and performance success in hospitals. USA: Dissertation. Walden University, 2010. 


\section{ZDRAVSTVENE ORGANIZACIJE I ODLUČIVANJE: STIL RUKOVOĐENJA ZA RAST I RAZVOJ}

\section{Sažetak}

Uvod: Upravljanje promjenama postalo je ključni instrument u svakoj organizaciji i presudan je za njihov opstanak jer su promjene postale neizbježne. Način na koji se promjene uvode u svakodnevnu praksu važna je komponenta upravljanja promjenama. Upravljanje promjenama uključuje promišljeno planiranje i provedbu, kao i uključivanje zaposlenika. Uspjeh se temelji na odgovarajućem pristupu upravljanju, budući da stilovi vodstva izravno utječu na uvođenje promjena transformiranjem stavova zaposlenika. Cilj istraživanja bio je ispitati utjecaj različitih stilova vodstva na uspjeh uvođenja promjena.

Metode: Primijenjena je kvantitativna metodologija. Instrument istraživanja bio je validirani upitnik s pitanjima zatvorenog tipa. Četiri slovenska doma zdravlja bila su uključena $u$ istraživanje.

Rezultati: Uspjeh uvedenih promjena statistički pozitivno korelira $s$ transformacijskim stilom vodstva $(p<0,05)$, a negativno $s$ laissez-faire stilom vodstva $(p<0,05)$. Procjena učinkovitosti stilova vodstva pozitivno korelira s transformacijskim, transakcijskim i laissez-faire stilom vodstva $(p<0,05)$. Međutim, jaka veza zabilježena je između transformacijskog stila vodstva i procijenjene učinkovitosti stilova vodstva i zadovoljstva uvedenim promjenama.

Zaključak: Tijekom proteklih desetljeća naglasak na promjeni pokazao se kao ključna značajka organizacijskog uspjeha. Promjene se uvode i temelje se na odgovarajućem stilu upravljanja koji ima izravan utjecaj na radno okruženje.
Ključne riječi: upravljanje promjenama, organizacijske promjene, zdravstvo, zdravstvene organizacije, stilovi vodstva, transformacijski stil vodstva, transakcijski stil vodstva, zadovoljstvo zaposlenika 